\title{
Time for an Open Dialogue on the Issue of Enthusiasm to Translate Stem Cells to Patients
}

\section{Pranela Rameshwar*}

UMDNJ-New Jersey Medical School, 185 South Orange Avenue, MSB E-585, Newark, NJ 07103, USA

The past decade has seen an 'explosion' on the numbers of papers, journals and scientific meetings focused on stem cell. These efforts, although seemed much, continue appropriately and have led to clinical trials. Admixed with the knowledge that further research studies are needed prior to clinical trials are those who show over-enthusiasm. The latter group, unknowingly, include patients, physicians and scientists, all of are willing to circumvent the available and common-sense ethical guidelines.

Although the information gained during the past decade on stem cell therapy has been impressive, one should remember that stem cell therapy is not a new form of therapy. Transplantation of hematopoietic stem cells in ablated bone marrow has been used for immune/blood reconstitution for $>50$ years. As groups began to prepare guidelines for what is considered as unethical practice, the members of such groups also need to ask if the practice is illegal. One should keep in mind that individually, approved formulations used in clinical settings could be legally combined for clinical application. These formulations, in combination with autologous tissue, for stem cell therapy are likely a legal practice. However, a practice that is legal might not be ethical and these two issues could be divided by a thin line, which could be easily crossed. As stem cells continue to indicate promise for different diseases, some of which currently have no cure, it is most likely that the different school of thoughts by scientists, ethicists, physicians and patient advocates will collide. Such discordance brings into focus the ethical boundaries currently being used in stem cell therapy.

In order to bring stem cells safely to patients, it is advisable that the scientific body and the ethicists who are drafting guidelines to include those who will be affected by the guidelines. Determining that healthcare individuals and scientists are distinct groups will be unproductive and ultimately, delay stem cell therapy. As the discussions proceed, questions should be asked on ethical and scientific issues. As an example, there are questions on the heterogeneity of human mesenchymal stem cells (MSCs). At present, it is difficult to determine if MSCs are indeed heterogeneous or an artifact of the culture methods. Thus far, questions such as the aforementioned are not addressed in the oversight, despite their fundamental relevance. In the absence of answers, stem cell therapy will continue to be inefficient and this will deter this form of treatment as authentic. This brings into question the identities of members of the group who advise the agencies that should be involved in ensuring safe, but efficient delivery of stem cells to patients.

One should remember that the physicians who are delivering the therapy are also interested in safety. It is interesting that among the request for proposal by governmental agencies, there is no focus on the safety of stem cells. One wonders if the oversight agencies are waiting for a disaster before safety issues are addressed.

Any discussion on stem cell therapy should not exclude the subject of cancer biology. This is especially important because of the identity of different subsets of tumor cells, including the putative cancer stem cells. At this time, it is unclear if stem cells will have a different effect on each cancer cell subset. Answers to these questions will require robust research. The information on stem cells and cancer support was studied for MSCs, which can support tumors through growth or providing an advantage to the tumors by suppressing the immune response [1-10]. While there are argument on the so-called tourist industry for stem cell therapy, lacking are specific safety issues such as the stem cell effects on undiagnosed cancer or in patients who might be in cancer remission. Ideally, it would be advisable to eradicate cancer and then deliver stem cells. However, cancer eradication is far from the near future, especially with the current focus on cancer cell subsets and the influence of the microenvironment in determining the behavior of the cancer cells [11]. An option is to consider how stem cells can be delivered to even patients with cancer. This will require robust experimental analyses, bringing into question if it is ethical to engage in tourist therapy with stem cell.

Another major consideration is the crosstalk between stem cells given to the patient and the microenvironment where the stem cell

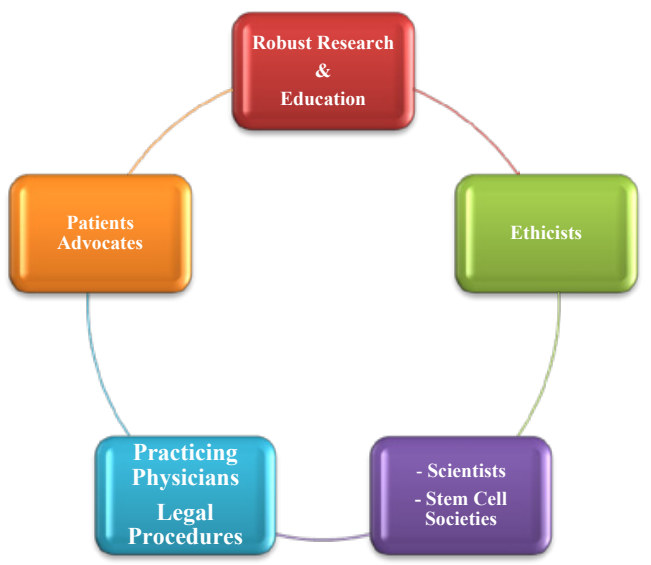

Figure 1: The cartoon shows the need for open dialogue among scientists, physicians, advocates, ethicists and regulatory agencies for the safe and efficient therapy. More importantly, stem cell education should be considered equally important to tamper the enthusiasm for immediate cure.

*Corresponding author: Pranela Rameshwar, Ph.D., UMDNJ-New Jersey Medical School, 185 South Orange Avenue, MSB E-585, Newark, NJ 07103, USA Tel: (973) 972-0625; Fax: (973) 972-8854; E-Mail: rameshwa@umdnj.edu

Received May 09, 2012; Accepted May 11, 2012; Published May 13, 2012

Citation: Rameshwar P (2012) Time for an Open Dialogue on the Issue of Enthusiasm to Translate Stem Cells to Patients. J Stem Cell Res Ther 2:e106. doi:10.4172/2157-7633.1000e106

Copyright: @ 2012 Rameshwar P. This is an open-access article distributed under the terms of the Creative Commons Attribution License, which permits unrestricted use, distribution, and reproduction in any medium, provided the original author and source are credited. 
Citation: Rameshwar P (2012) Time for an Open Dialogue on the Issue of Enthusiasm to Translate Stem Cells to Patients. J Stem Cell Res Ther 2:e106. doi:10.4172/2157-7633.1000e106

might home and integrate. Stem cells can initiate a communication with cells within a injured tissue, which might express inflammatory mediators. Stem cells would be able to establish crosstalk with cells within the site if injury because they express receptors for inflammatory mediators and they can also respond by producing cytokines and other factors [12]. Thus, it is important to understand how stem cells will respond within an area of tissue injury and whether this could be a question of safety before stem cells are given to patients.

Scientists in academia do not have the business background and for the most part, lacked the knowledge on key regulatory issues. Going forward, stem cell societies should include non-members, patient advocates, practicing physicians and individuals from companies (Figure 1). An open process should be encouraged with input from the stakeholders who are also those individuals who are engaged in touristtype stem cell therapy. By excluding the input from all and, to have a closed process will be more harmful and delay stem cell therapy to patients.

\section{Acknowledgement}

This work was supported by the FM Kirby Foundation.

\section{References}

1. Patel SA, Meyer JR, Greco SJ, Corcoran KE, Bryan M, et al. (2010) Mesenchymal Stem Cells Protect Breast Cancer Cells through Regulatory $T$ Cells: Role of Mesenchymal Stem Cell-Derived TGF-beta. J Immunol 184: 5885-5894.

2. Comsa S, Ciuculescu F, Raica M (2012) Mesenchymal stem cell-tumor cell cooperation in breast cancer vasculogenesis. Mol Med Report 5: 1175-1180.
3. Momin EN, Vela G, Zaidi HA, Quiñones-Hinojosa A (2010) The Oncogenic Potential of Mesenchymal Stem Cells in the Treatment of Cancer: Directions for Future Research. Curr Immunol Rev 6: 137-148.

4. Feng B, Chen L (2009) Review of mesenchymal stem cells and tumors: executioner or coconspirator? Cancer Biother Radiopharm 24: 717-721.

5. Rameshwar P (2010) Breast cancer cell dormancy in bone marrow: potential therapeutic targets within the marrow microenvironment. Expert Rev Anticancer Ther 10: 129-132.

6. Greco SJ, Rameshwar P (2008) Microenvironmental considerations in the application of human mesenchymal stem cells in regenerative therapies. Biologics 2: 699-705

7. Riggi N, Suva ML, De VC, Provero P, Stehle JC, et al. (2010) EWS-FLI-1 modulates miRNA145 and SOX2 expression to initiate mesenchymal stem cell reprogramming toward Ewing sarcoma cancer stem cells. Genes Dev 24: 916 932.

8. De Boeck A, Narine K, De Neve W, Mareel M, Bracke M, et al. (2010) Resident and bone marrow-derived mesenchymal stem cells in head and neck squamous cell carcinoma. Oral Oncol 46: 336-342.

9. Corcoran KE, Trzaska KA, Fernandes H, Bryan M, Taborga M, et al. (2008) Mesenchymal stem cells in early entry of breast cancer into bone marrow. PLoS One 3: e2563.

10. Mishra PJ, Mishra PJ, Humeniuk R, Medina DJ, Alexe G, et al. (2008) Carcinoma-Associated Fibroblast-Like Differentiation of Human Mesenchymal Stem Cells. Cancer Res 68: 4331-4339.

11. Badve S, Nakshatri H (2012) Breast-cancer stem cells-beyond semantics. The Lancet Oncol 13: e43-e48.

12. Liu X, Duan B, Cheng Z, Jia X, Mao L, et al. (2011) SDF-1/CXCR4 axis modulates bone marrow mesenchymal stem cell apoptosis, migration and cytokine secretion. Protein Cell 2: 845-854. 